\title{
Seventy-Five Years of Racial Ethnic Diversity in Atla
}

Susan Ebertz, Wartburg Theological Seminary

\begin{abstract}
Some of the events of the past year have resulted in theological institutions assessing their own racial ethnic diversity and making plans for increasing that diversity. This year Atla celebrates seventy-five years of existence. This session will reflect back over the past 75 years and note what has been done. The presentation given at the ATLA Annual Conference in 2011, Sixty-Five Years of Racial Ethnic Diversity in ATLA will be the basis for the session. At the conclusion of the 2011 presentation, the vision of the future was of an association which reflected the general population in terms of percentage of racial ethnic persons. The session will chronicle events from the last 10 years, update data, and see how close to that vision the association has come. Areas of possible growth will also be noted.
\end{abstract}

I acknowledge that Wartburg Theological Seminary, in Dubuque, Iowa, USA, sits on the traditional, ancestral, and unceded territory of the Sauk and Meskwaki, Miami, Iowa, Ho Chunk, Potawatami and Očhéthi Šakówin peoples.

At the 2011 Atla Annual Conference, I did a presentation on "SixtyFive Years of Racial Ethnic Diversity in ATLA” (Ebertz 2011, 271-87). This session will focus on the past ten years. I am limiting what I say here to racial ethnic diversity in Atla in the USA and will be using the term BIPOC (Black, Indigenous, and People of Color), which is more common today than racial ethnic. In recent years, the Committee for DEI has sponsored innovative activities which have included other marginalized groups. I applaud them for their good work. As many of you know, in terms of diversity my interests lie in the issues of BIPOC diversity. As with the 2011 session, I will begin with numbers and graphs. They are to show the context of Atla's diversity and the change since 2011. It seemed more difficult to find information this time around. I think the pandemic made a difference in this. I have not been actively involved with the diversity committee since 2011 when the initial committee ended. Most of the information is from the diversity committee reports in the Summary of Proceedings, and beginning in 2018, the Atla Annual Yearbook. Some of the information in this paper is limited by my own knowledge of Atla members. I welcome anyone to help correct the record. 


\section{UNITED STATES POPULATION}

The following graph is from the Visual Capitalist website (Ghosh 2020) and shows the USA population by race in 2019. Beige is White. Orange is Hispanic. Blue is Black. Brown is Asian. Black is Multiple Races. Red is American Indian/Alaskan Native. Green is Native Hawaiian/Other Pacific Islander. As you can probably see White is $60 \%$ and BIPOC is $40 \%$.

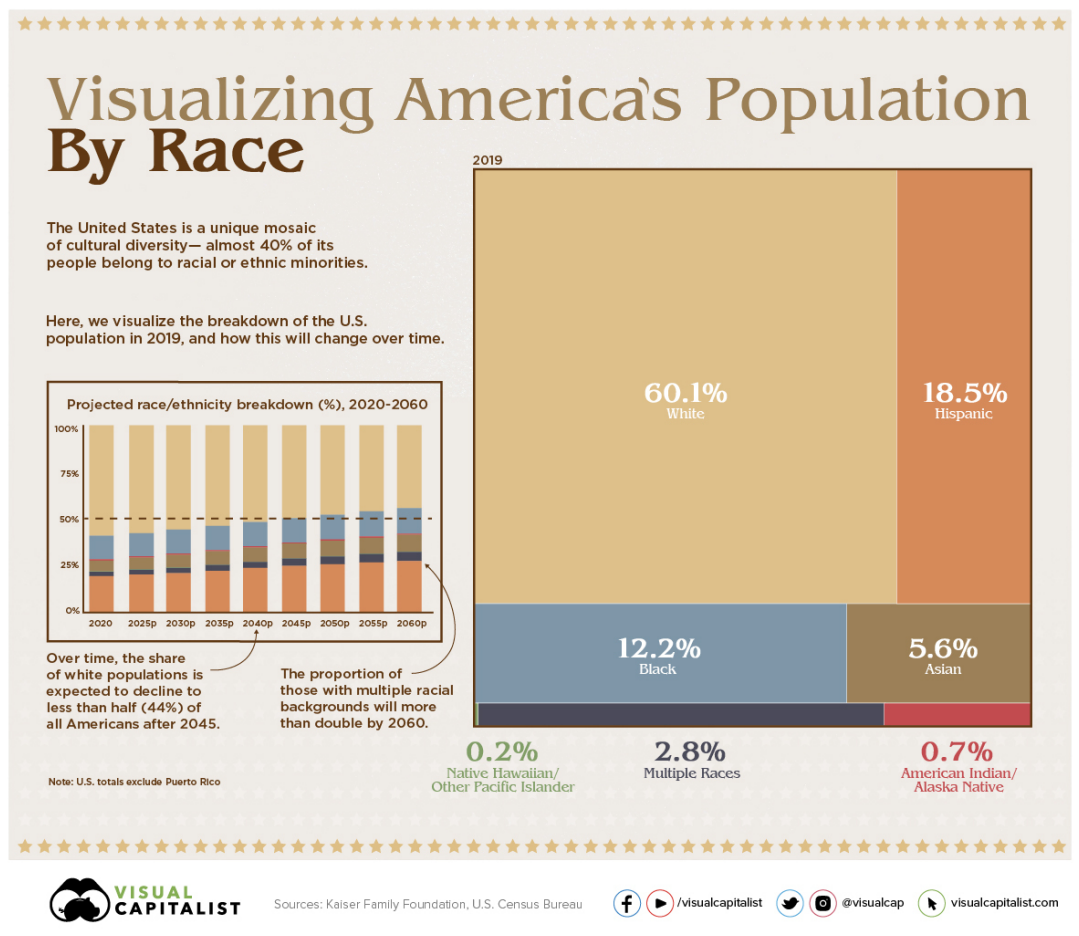

I thought it was interesting that the graph did not include Puerto Rico which is $98 \%$ Hispanic. The bar graph on the left uses the same color scheme. As you can see the beige section decreases while the others increase.

The United States Census Bureau report, "Demographic Turning Points for the United States: Population Projections for 2020 to 2060" (Vespa, Medina, and Armstrong 2020,3) gives these numbers and percentages. You can see the population demographics change over the years, and that the projection is that by 2060, BIPOCs will be the majority. 


\begin{tabular}{|c|c|c|c|c|c|c|}
\hline & \multicolumn{2}{|c|}{2016} & \multicolumn{2}{|c|}{2030} & \multicolumn{2}{|c|}{2060} \\
\hline & Number & Percent & Number & Percent & Number & Percent \\
\hline Total & $323,128,000$ & 100 & $355,101,000$ & 100 & $404,483,000$ & 100 \\
\hline White & $248,503,000$ & 76.9 & $263,453,000$ & 74.2 & $275,014,000$ & 68 \\
\hline $\begin{array}{l}\text { Non-Hispanic } \\
\text { White }\end{array}$ & $197,970,000$ & 61.3 & $197,992,000$ & 55.8 & $179,162,000$ & 44.3 \\
\hline $\begin{array}{c}\text { Black/African } \\
\text { American }\end{array}$ & $43,001,000$ & 13.3 & $49,009,000$ & 13.8 & $60,690,000$ & 15.0 \\
\hline $\begin{array}{c}\text { American } \\
\text { Indian/Alaska } \\
\text { Native }\end{array}$ & $4,055,000$ & 1.3 & $4,663,000$ & 1.3 & $5,583,000$ & 1.4 \\
\hline Asian & $18,319,000$ & 5.7 & $24,394,000$ & 6.9 & $36,815,000$ & 9.1 \\
\hline $\begin{array}{c}\text { Native } \\
\text { Hawaiian/ } \\
\text { Other Pacific } \\
\text { Islander }\end{array}$ & 771,000 & .02 & 913,000 & .03 & $1,125,000$ & .03 \\
\hline $\begin{array}{c}\text { Two or More } \\
\text { Races }\end{array}$ & $8,480,000$ & 2.6 & $12,669,000$ & 3.6 & $25,255,000$ & 6.2 \\
\hline Hispanic & $57,470,000$ & 17.8 & $74,807,000$ & 21.1 & $111,216,000$ & 27.5 \\
\hline
\end{tabular}

\section{ASSOCIATION OF THEOLOGICAL SCHOOLS}

The Association of Theological Schools accredits theological schools in Canada and the US (ATS, n.d.). Once a year the schools must fill out a survey. The schools self-report on how they see themselves. The 2020 survey has $17 \%$ self-identifying as BIPOC, with $71 \%$ White. The other $12 \%$ is made of schools with majority visa students and schools that did not report.

\begin{tabular}{|c|c|c|}
\hline Racial/ethnicity & Number of ATS schools & Percentage of ATS schools \\
\hline Asian/Pacific Islander & 3 & $1.4 \%$ \\
\hline Black non-Hispanic & 9 & $4 \%$ \\
\hline Hispanic & 3 & $1.4 \%$ \\
\hline American Indian/Alaskan Native & 0 & 0 \\
\hline Multi-racial/ethnic & 10 & $4.5 \%$ \\
\hline White & 179 & $81 \%$ \\
\hline Visa & 5 & $2.2 \%$ \\
\hline Not Reported & 13 & $5.9 \%$ \\
\hline Total & 222 & \\
\hline
\end{tabular}


I adjusted the ATS numbers by taking out the schools that have a majority of visa students and those that did not report. This makes it easier to compare with the graph of the US population from Visual Capitalist (above). The results of doing this shows ATS as $81 \%$ White and BIPOC as $19 \%$ as compared to the US population with $60 \%$ White and BIPOC as $40 \%$.

\begin{tabular}{|c|c|c|}
\hline & ATS schools & US population \\
\hline White & $81 \%$ & $60 \%$ \\
\hline BIPOC & $19 \%$ & $40 \%$ \\
\hline
\end{tabular}

Information about US ATS schools is found in the Annual Data Tables, Table 1.2, "Significant Institutional Characteristics of Each Member School.” In comparing the number of ATS schools in 2010 with 2020, we see that there has been some growth in diversity. In 10 years the number of self-identified BIPOC schools increased from $11.3 \%$ to $17 \%$. Schools with a majority of students on visas or not reported also increased. This accounts for the lower number of White schools (from 81\% to $71 \%$ ).

\begin{tabular}{|c|c|c|c|c|}
\hline US ATS Schools & \multicolumn{2}{|c|}{2010} & \multicolumn{2}{c|}{2020} \\
\hline & Number & Percent & Number & Percent \\
\hline Racial Ethnic & 25 & 11.3 & 39 & 17 \\
\hline Asian, Pacific Islander & 3 & 1.35 & 7 & 3 \\
\hline Black Non-Hispanic & 9 & 4 & 14 & 6 \\
\hline Hispanic & 3 & 1.35 & 7 & 3 \\
\hline American Indian, Alaskan Native, or Inuit & 0 & 0 & 0 & 0 \\
\hline Multi-racial/ethnic & 10 & 4.5 & 11 & 4.8 \\
\hline Visa & 5 & 2.2 & 9 & 4 \\
\hline White & 179 & 80.6 & 164 & 71.3 \\
\hline Not Reported & 13 & 5.9 & 18 & 7.8 \\
\hline Total & 222 & & 230 & \\
\hline
\end{tabular}

The number of BIPOC ATS schools increased from 25 in 2010 to 39 in 2020. In the table, 39 ATS schools self-identified as BIPOC schools in the 2020 survey: Asian 7, Black 14, Hispanic 7, and Multi-racial 11. As of June 2021, the fourteen schools in the list below with an asterisk are not members of Atla.

Alliance Theological Seminary* 
Azusa Pacific Seminary* $\quad \mathrm{H}$

B. H. Carroll Theological Institute M

Baptist Seminary of Kentucky M

Barry University Department of Theology \& Philosophy $\quad \mathrm{H}$

Berkeley School of Theology (CA) M

Candler School of Theology $\quad M$

Christian Witness Theological Seminary A

Drew University Theological School M

Ecumenical Theological Seminary* B

Evangelical Seminary of Puerto Rico $\quad \mathrm{H}$

Gateway Seminary M

Grace Mission University Graduate School A

Graduate School of Theology \& Ministry in PR* $\quad \mathrm{H}$

Grand Canyon Theological Seminary B

Henry Appenzeller University* A

Hood Theological Seminary* B

Houston Graduate School of Theology B

Howard University School of Divinity B

Inter-American Adventist Theological Seminary* $\quad M$

Interdenominational Theological Center B

John Leland Center for Theological Studies M

Logos Evangelical Seminary A

McCormick Theological Seminary B

Memphis Theological Seminary B

Midwest University Graduate School of Theology* A

Neal T. Jones Seminary of Washington University of VA* M

New Brunswick Theological Seminary $\quad M$

New York Theological Seminary* M

Oakwood University School of Religion Grad Dept* B

Oblate School of Theology $\quad \mathrm{H}$

Payne Theological Seminary B

Presbyterian Theological Seminary in America* A

Regent University School of Divinity B

Samuel DeWitt Proctor School of Theology* B

Shaw University Divinity School* B

St. John's Seminary (CA) H

United Theological Seminary $\quad$ B

World Mission University $\quad$ A 
We turn now to the racial/ethnic demographics of the students at US ATS schools. This information is found in Table 2.12-B "Head Count Enrollment by Race or Ethnic Group, Degree, and Gender.”

\begin{tabular}{|c|c|c|c|c|}
\hline US ATS Students & \multicolumn{2}{|c|}{2010} & \multicolumn{2}{c|}{2020} \\
\hline Racial Ethnic & Number & Percent & Number & Percent \\
\hline Asian, Pacific Islander & 17,005 & 24.1 & 23,012 & 31.4 \\
\hline Black Non-Hispanic & 4,451 & 6.32 & 6,021 & 8.2 \\
\hline Hispanic & 8,850 & 12.57 & 9,410 & 12.8 \\
\hline American Indian, Alaskan Native, or Inuit & 230 & .33 & 5,654 & 7.7 \\
\hline Multi-racial/ethnic & & & 1,693 & 2.3 \\
\hline Visa & 6,321 & 8.97 & 7,243 & 9.9 \\
\hline White & 41,586 & 59 & 37,386 & 51 \\
\hline Not Reported & 5,520 & 7.8 & 5,687 & 7.8 \\
\hline Total & 70,432 & & 73,328 & \\
\hline
\end{tabular}

We see that the number of BIPOC students has increased from $24.1 \%$ to $31.4 \%$ and the White students have decreased from $59 \%$ to $51 \%$.

The racial ethnic diversity of the faculty at US ATS schools have also changed in the ten years. BIPOC faculty have increased from $17.45 \%$ to $23.5 \%$ and White faculty have decreased from $81 \%$ to $73.9 \%$. However, the percentages are very different from the US ATS students. In 2020, 31.4\% of the US ATS students are BIPOC while faculty are $23.5 \%$. White students in 2020 are $51 \%$ compared to faculty at $73.9 \%$. Faculty racial ethnic diversity lags behind students.

\begin{tabular}{|c|c|c|c|c|}
\hline US ATS Faculty & \multicolumn{2}{|c|}{2010} & \multicolumn{2}{c|}{2020} \\
\hline Racial Ethnic & Number & Percent & Number & Percent \\
\hline Asian, Pacific Islander & 575 & 17.45 & 678 & 23.5 \\
\hline Black Non-Hispanic & 185 & 5.6 & 251 & 8.7 \\
\hline Hispanic & 258 & 7.8 & 265 & 9.2 \\
\hline American Indian, Alaskan Native or Inuit & 120 & 3.6 & 141 & 4.9 \\
\hline Multi-racial/ethnic & 8 & .12 & 1 & .03 \\
\hline Visa & 26 & .24 & 20 & .69 \\
\hline White & 2,671 & 81 & 2,128 & 73.9 \\
\hline Not Reported & 24 & .73 & 57 & 2 \\
\hline Total & 3,296 & & 2,879 & \\
\hline
\end{tabular}




\section{ATLA MEMBERSHIP}

Atla member demographics are more difficult to obtain since the only instrument used is membership surveys. Participation in the survey is completely voluntary. Numbers may be skewed by the fact that institutional representatives may also be individual members. Some libraries may have library staff who are not either the institutional representative or an individual member. The numbers then are not reflective of the staff at Atla member libraries.

These are the results of the Atla membership surveys in 2010. Information was accessed in 2011 and is no longer available using the link in Works Cited (Atla 2011).

\begin{tabular}{|c|c|c|c|c|}
\hline ATLA Survey 2010 & \multicolumn{2}{|c|}{ Institutional Rep } & \multicolumn{2}{c|}{ Individual Member } \\
\hline & Number & Percent & Number & Percent \\
\hline Racial Ethnic & 8 & 5.9 & 29 & 10.4 \\
\hline Asian, Pacific Islander & 8 & 5.9 & 7 & 2.5 \\
\hline Black Non-Hispanic & & & 7 & 2.5 \\
\hline Hispanic & & & 5 & 1.8 \\
\hline American Indian, Alaskan Native or Inuit & & & 1 & .36 \\
\hline Multi-racial/ethnic & & & 9 & 3.2 \\
\hline Other & 8 & 5.9 & & \\
\hline White & 115 & 85.2 & 243 & 87.4 \\
\hline No Answer & 4 & 3 & 6 & 2.2 \\
\hline Total & 135 & & 278 & \\
\hline
\end{tabular}

Atla Individual Membership survey conducted in 2019 reported the following. The numbers of BIPOC survey participants have increased in the nine years. The percentages are lower than the US ATS faculty and far lower than the US ATS students. 


\begin{tabular}{|c|c|c|c|c|c|}
\hline \multicolumn{7}{|c|}{ Atla Individual Member Survey 2019 } \\
\hline $\begin{array}{c}\text { Racial } \\
\text { Ethnic }\end{array}$ & & Number & Percent & Number & Percent \\
\hline & Black or African American & & & & 12.13 \\
\hline & Asian & & 5.71 & & \\
\hline & $\begin{array}{c}\text { Hispanic, Latino, } \\
\text { or Spanish Origin }\end{array}$ & & 2.14 & & \\
\hline & Native American & & 2.86 & & \\
\hline White & Multi-racial/ethnic & & .71 & & \\
\hline Other & & & 85 & & \\
\hline No Answer & & & .71 & & \\
\hline Total & & & 4.29 & & \\
\hline
\end{tabular}

I gathered some information from the US Department of Labor, Bureau of Labor Statistics, and looked at the category "Librarians and media collections specialists" (U.S. Bureau of Labor Statistics. 2020). The racial ethnic groups listed were Black/African American, Asian, and Hispanic/Latino. The US Department of Labor information shows $21 \%$ BIPOC, which is a much higher percentage than the Atla membership survey.

\begin{tabular}{|l|l|c|c|c|c|}
\hline \multicolumn{6}{|c|}{ U.S. Department of Labor, Bureau of Labor Statistics, Labor Force Statistics from the Current } \\
Population Survey 2020 \\
\hline
\end{tabular}




\section{ATLA ANNUAL SESSIONS AND ACTIVITIES}

Below is a list of the number of sessions and activities since 1973. The information is pulled from the Summary of Proceedings. As I mentioned in the introduction, the designation of whether a session or activity is considered dealing with BIPOC issues is based on my decision.

$\begin{array}{llll}1973 & 1 & 2010 & 2 \\ 1974-97 & 0 & 2011 & 3 \\ 1998 & 2 & 2012 & 7 \\ 1999-2000 & 0 & 2013 & 3 \\ 2001 & 2 & 2014 & 1 \\ 2002-03 & 0 & 2015 & 3 \\ 2004 & 1 & 2016 & 5 \\ 2005 & 1 & 2017 & 2 \\ 2006 & 2 & 2018 & 1 \\ 2007 & 1 & 2019 & 2 \\ 2008 & 1 & 2020 & 2 \\ 2009 & 1 & & \end{array}$

In the 1973 Proceedings, Carol Moldovanyi wrote a plea for recruitment of minority persons as theological librarians (Moldovanyi, 1973). Her comments, though well-meaning, seem to indicate that minority persons were poor with substandard living conditions. This stereotyping seems to demonstrate the attitude of that time. However, Atla is to be commended on being concerned about diversifying their ranks even as early as 1973.

This is a list of Conference sessions that I gleaned from the Summary of Proceedings. I made the determination of whether or not they were BIPOC session.

2012 Plenary Address: "What's for Lunch? Serving a Diversity Salad \& Sharing a Recipe for Organizational Change,” Dr. Camila A. Alire

2012 Paper: "Stories of Our Past as Parables of Our Present: Japanese American Internment Camps in Arizona," Susan Ebertz

2012 Panel: "How Do 'They' Do It? Digital Initiatives and Electronic Resources, an International Panel of Specialists," Mariel Deluca, Daniel Flores, Rob Bradshaw, Cindy Lu Wu

2012 Conversation Group: "The Changing Face of Evangelical Seminary Students,” Charles Kamilos, Suzanne Smith 
2013 Conversation Group: "11 Million Reasons to Become Diverse: How Diverse Populations are Changing Libraries and Society,” Stephen V. Sweeney

2014 Conversation Group: "Preserving and Sharing Meditations of Howard Thurman: Digitization and Transcription of Audio Archives at the Pitts Theology Library,” Richard Manly Adams, Jr.

2015 Pre-Conference Workshop: "Racial Equity in Theological Librarianship,” Lynn Berg, Emily Braucher, Susan Ebertz, Martin Garnar, Adrienne Mansanares, Shaneè Yvette Murrain, Warren Watson

2015 Papers \& Presentations: "Beyond the Number: Diversity Management in Academic Theological Libraries," Jaeyeon Lucy Chung

2015 Conversations Group: "Keep Your Eyes on the Prize: The Continuing Work for Equity, Diversity, and Inclusion," Martin Garnar, Gabriel Ortiz

2016 Plenary: "How Can ATLA Transform Diversity into Inclusivity to Drive Innovation?”, Rahuldeep Gill

2016 Papers \& Presentations: “Theology, Race and Libraries,” Anita Coleman

2016 Panel Discussion: "The Silence of the Religious Archive on Issues of Social Justice: Exploring the Political Activity of Two Denominations Through Primary Source Materials," Christopher J. Anderson, Colin Dube, Shaneè Yvette Murrain

2017 Listen \& Learn: "The Human Rights of Muslims in the United States: How is the Question Irrelevant?”, Dr. Abdullahi Ahmed An-Na'im, Emory Law School, sponsored by the Committee on Diversity, Equity, and Inclusion

2017 Listen \& Learn: "The Implications of Relevance Theory for Cross-Cultural Library Communication,” Wesley Custer

2018 In-Conference Workshop: "Slave Narratives, the Bible and Hymns, Oh My...,” Joshua Been and Bill Hari

2019 Papers \& Presentations: "Global Learning and the Myth of Borders," Anthony J. Elia

2019 Listen \& Learn: "First Nations/Native Americans and Religion," Jane Lenz Elder and David Schmersal

2020 Conversation Group: "Theological Libraries Serving Immigrant Communities," Susan Ebertz

2020 Poster: "Black Theology Papers Project," Andrea C. White and Adam Clark 
I created this list of conference activities from the Summary of Proceedings:

2012 Excursion: Native Cultures and Plants of the Southwest

2012 Worship: Spiritual Discipline of Meditation, Spiritual Discipline of Service

2012 Movie Night: "Rabbit Proof Fence" with discussion of the movie

2013 Worship in the African-American tradition, Dr. Gregory Moss

2013 Movie Night: "Water" with discussion of the movie

2016 All Conference Lunch: "Are You Welcomed? A Conversation Toward Building a More Diverse and Inclusive Community in ATLA"

2016 Poster session: "Committee's history, and its new direction and charge, and offer a space for members to leave personal responses and reflections on their views of the new charge and what it would mean for the future."

\section{ATLA DIVERSITY COMMITTEE}

Information about the Atla diversity committee in its different forms comes from my own experience and from the Summary of Proceedings and later the Yearbook (Atla, n.d.). The Special Committee on Diversity was created in 2008 to meet the Association Ends. At that time the Association Ends were:

1.3 ATLA reflects the diversity of our communities and institutions, including but not limited to religious, racial, ethnic, and gender diversities.

1.3.1 Individuals from under-represented racial and ethnic minority communities are welcomed as members of the association and are encouraged to hold leadership roles.

The Committee's Charge was:

1) Receive applications; evaluate and select recipients of ATLA Scholarships for Minorities;

2) Represent the Association at meetings of the ATLA Affiliates Organization; 
3) Gather information about the diversity efforts of other library associations and explore possibilities for collaboration;

4) Promote, plan and monitor Annual Conference programs related to diversity;

5) Investigate potential connections between racial diversity and other forms of diversity within the association.

In 2012, there is no indication in the Proceedings that a diversity committee existed.

In 2012-13 the Diversity Committee was created with a new charge which was approved by the ATLA Executive Director. The charge is as follows:

The Diversity Committee recommends practices and programs related to recruitment, retention, development, and advancement of diverse members; receives applications, evaluates, and selects recipients for the ATLA Scholarship to Promote Diversity in Theological Librarianship; encourages collaborative relationships with communities of diverse professionals; ensures diverse perspectives in programs at the ATLA Annual Conference and other activities of the association; promotes research that supports diversity in theological and religious studies libraries; and shares resources and services related to issues of diversity.

The members of the committee were Stephen Sweeney (chair), Lynn Berg, Daniel Flores, and Stella Wilkins. Their activities included awarding scholarships and beginning a Diversity Resource List.

The members of the committee in 2014 were Daniel Flores (chair), Lynn Berg, Jaeyeon Lucy Chung, and Stella Wilkins. Activities included awarding scholarships, creating an Atla Diversity webpage with resources, and continuing the Listserv.

The members of the committee in 2015 were Lynn Berg (chair), Jaeyeon Lucy Chung, Shaneè Yvette Murrain, and Gabriel Ortiz. Activities included "informal dinner gathering of diversity-minded folks at a local restaurant" during the conference.

In 2016, the name was changed to Committee for Diversity, Equity, and Inclusion (DEI). The members of the committee were Lucy Chung and Nic Weiss (co-chairs), Bonggun Baek, Shaneè Yvette Murrain, and Gabriel Ortiz. Activities included Committee attending the 2015 Parliament of the World's Religions and awarding two scholarships.

New charge:

In order to realize and live the core values of hospitality, inclusion, and diversity as outlined in the ATLA Strategic Plan, the Committee for Diversity, Equity, and Inclusion (DEI) is committed to advancing 
ATLA's culture that affirms the intrinsic value of all members regardless of racial, culture, age, career stage/professional experience, sexual orientation, gender expression, expression of faith tradition, disabilities, or socio-economic differences by:

- identifying, acknowledging, and deconstructing barriers to diversity, equity, and inclusion

- welcoming, valuing, and celebrating multiple perspectives and cultural vantage points

- increasing awareness and sensitivity toward issues of diversity, equity, and inclusion

- modeling meaningful exchange and full community participation

- creating and maintaining a welcoming and respectful environment

- embedding diversity, equity, and inclusion into the work and outcomes of the association

- providing members with resources, tools, and best practices they can use at their own institutions as appropriate

- transforming ATLA's composition to reflect the diversity of members' institutions and communities

The members of the committee were Nicholas Weiss (chair 7/20162/2017), Donna Wells (chair 2/2017-6/2017), Evan Boyd, Ondrea Murphy, Drew Baker, and Lee Staman. Activities included sponsoring a three-part webinar: "Making Your Library a Place for Meaningful Conversation” with Myka Kennedy Stephens, "Librarians as Active Bystanders: Centering Social Justice in LIS Practice" with Nichole Amy Cooke, and "Let's Talk about Power: Why Diversity and Cultural Competence are Important to LIS” with Nichole Amy Cooke. The committee awarded scholarships and sponsored a poster session at the conference to raise awareness of the DEI scholarship.

In 2018, the members of the committee were Donna Wells (chair), Ondrea Murphy, Evan Boyd, Lee Staman, and Drew Baker. Activities included creating a three-year plan of action, contacting library schools about the diversity scholarship and raising the amount of the scholarship, hosting a webinar series, and creating an oral history project. At the Annual Conference, the committee sponsored a Listen and Learn: "Are We All Saints? How One Church Has Strived for Radical Welcome and Inclusion in Their Congregation,” presented by 
Suzanne Wille, Episcopal Church of All Saints of Indianapolis. The committee also sponsored with the World Religions Interest Group an interfaith discussion on a movement called Focolare. There was a poster session to gauge interest in a webinar series.

In 2019, the committee members were Evan Boyd (chair), Drew Baker, Ondrea Murphy, Lee Staman, Alice Song, and Donna Wells. Activities included reassessing aspiration projects and laying ground for future planning and projects. Because of staffing changes related to the committee, the committee was not able to have as many programs. The committee did develop several monthly blog posts focusing on how members can support diversity at their institutions, including a summary of deaf and Deaf community history, and a celebration of Asian American and Pacific American Heritage Month. The committee granted a diversity scholarship. At Atla Annual the committee sponsored "Building Inclusive Spaces: Vancouver Public Library's Trans, Gender Variant, and two-Spirit Inclusion Initiative” Alex MacCutchan.

In 2020, the committee members were Evan Boyd (chair 7/20195/2020), Yasmine Abou-El-Kheir (chair 7/2020-8/2020), Daniel (Bonggun) Baek, David Kriegh, Alice Song, and Donna Wells. Activities included six blogposts to the Atla blog:

- "Transgender Day of Remembrance, November 20" by Evan Boyd.

- A guest post by Tomoko Shida, the recipient of the 2019 Atla Diversity, Equity, and Inclusion Scholarship, on "'Hospitality” in Archival Collections Related to the Study of Religion.”

- Reflections by all DEI Committee members on the meaning of diversity, equity, and inclusion.

- "African Americans and the Ballot Box: Countering Disinformation Campaigns with Social Media Literacy" by Yasmine AbouEl-Kheir.

- A guest blog post by Sheryl Stahl, director of the Hebrew Union College-Jewish Institute of Religion, discussing "Yom ha-Shoah (Israeli Holocaust Remembrance Day).”

- "Asian Pacific American Heritage Month (APAHM): A Rich Mosaic” by Daniel (Bonggun) Baek

Scholarships were awarded, a DEI lib guide was created, and a survey was developed. The committee approached the board 
concerning a statement on the deaths of George Floyd, Ahmaud Arberry, and Breonna Taylor.

This is the Mission and Organizational Ends statement adopted by the Atla Board of Directors in February 2020. I've highlighted the end which deals with diversity, inclusion, equity, and antiracism.

The Board and Membership of the Association adopted a mission statement and Organizational Ends to guide the Association's activities and programs:

The mission of Atla is to foster the study of theology and religion by enhancing the development of theological and religious studies libraries and librarianship.

Atla exists so that:

Librarians and information providers in theology and religion are connected in a sustainable and diverse global community at a cost that demonstrates good stewardship of resources.

This is further defined to include but not limited to the following:

1. Users have access to quality academic and professional resources.

1.1 Open access resources and special collections are available and discoverable by librarians and information professionals.

2. Institutional leaders have an awareness of the trends impacting the religion and theology library ecosystem.

3. Librarians and information providers are growing in their competencies and skills.

\subsection{Librarians and information providers demonstrate competencies in diversity, inclusion, equity, and antiracism.}

3.2 Information professionals are able to successfully navigate the changing landscape.

3.3 Librarians and information providers have access to professional development in technical and digital skills.

3.4 Information professionals have opportunities to innovate.

Here's a list of BIPOC persons (as far as I could tell) who have been/are on the Atla Board of Directors.

- Carrie Hackney (2009-15)

- Tammy Johnson (2012-2014)

- Jaeyeon Lucy Chung (2016-2018) 
- Shaneè Yvette Murrain (2018-2021)

- Susan Ebertz (2019-2022)

- Yasmine Abou-El-Kheir (2021-2024)

Here's a list of BIPOC persons (again as far as I could tell) who have been/are on Atla Committees other than the diversity committee.

- Mariel Deluca Voth: International Collaboration (chair), 2012

- Cindy S. Lu: International Collaboration, 2012-2014

- Lisa Gonzalez: Publications, 2012-2014

- Carrie Hackney: Nominating, 2014

- Tammy Johnson: Nominating, 2016-2017

- Shaneè Yvette Murrain: Conference, 2017-2018

- Yasmine Abou-El-Kheir: Professional Development, 2017-2020

- Gerone Lockhart: Conference, 2019-2020

- Sabahat Adil: Scholarly Communication, 2019-2020

I just did a whirlwind tour of the history of the last ten years plus. As I mentioned in the description of the session, "At the conclusion of the 2011 presentation, the vision of the future was of an association that reflected the general population in terms of the percentage of BIPOC persons. The session will chronicle events from the last 10 years, update data, and see how close to that vision the Association has come.”

I was struck by three of my discoveries. One was comparing the Atla member survey results from 2010 to 2019 and seeing the increase of BIPOC diversity. In the 2010 survey $10.4 \%$ was BIPOC and in $202012.13 \%$. The second one was comparing the Atla member survey with the ATS US students. There was a significant difference in the percentages. Atla 12.13\%; ATS students $31.4 \%$. The third one was the number of sessions and activities at Atla Annual. The numbers definitely increased. I didn't include the numbers from this conference, but they were significant.

I wonder what goals, takeaways, and strategies for change you may have. Is one of the goals to increase the percentage of BIPOC persons within Atla? Is there a reason to do this? I was struck by our opening speaker, Alexia Hudson-Ward. She spoke of failing forward. I asked the question during the Q\&A about what we can do when others want us to fail or see failure as failure and not as opportunity. 
She mentioned the laboratory, and it made me think that our strategies may not always succeed but we are still trying, and we learn from our failures. The other point was about polymath behavior. We often think of things like this from an individual perspective. But we can see polymath behavior as a group behavior and the need for many diverse voices to bring about something wonderful.

\section{WORKS CITED}

American Theological Library Association. 2011. "2011 Direct Inspection A: Membership.” Accessed June 8, 2011. http://www. atla.com/community/ATLA\%20Member\%20Publications/MSD_ report_rev_2011.pdf.

Association of Theological Schools (ATS). n.d. "Annual Data Tables.” Accessed May 10, 2021. https://www.ats.edu/resources/institutional-data/annual-data-tables.

Atla. n.d. Atla Annual Yearbook. https://serials.atla.com/yearbook/ issue/archive.

Atla. n.d. Atla Summary of Proceedings. https://serials.atla.com/ proceedings/issue/archive.

Ebertz, Susan. 2011. "Sixty-Five Years of Racial Ethnic Diversity in ATLA.” ATLA Summary of Proceedings, edited by S. Corkery, 271-87. Chicago: American Theological Library Association.

Ghosh, Iman. 2020. "Visualizing the U.S. Population by Race."

Accessed June 10, 2021. https://www.visualcapitalist.com/visualizing-u-s-population-by-race/.

Moldovanyi, Carole Ann. 1973. "Recruitment of Minority Persons for Theological Librarianship.” ATLA Summary of Proceedings 27: 90-91.

U.S. Bureau of Labor Statistics. 2020. "Labor Force Statistics from the Current Population Survey.” Accessed May 10, 2021. https://www. bls.gov/cps/cpsaat11.htm

Vespa, Jonathan, Lauren Medina, and David M. Armstrong. "Demographic Turning Points for the United States: Population Projections for 2020 to 2060.” Accessed June 10, 2021. https://www. census.gov/content/dam/Census/library/publications/2020/demo/ p25-1144.pdf. 